\title{
Dietary sources of five nutrients in ethnic groups represented in the Multiethnic Cohort
}

\author{
Sangita Sharma ${ }^{1 *}$, Lynne R. Wilkens ${ }^{2}$, Lucy Shen ${ }^{2}$ and Laurence N. Kolonel ${ }^{2}$ \\ ${ }^{1}$ Department of Medicine, University of Alberta, 5-10 University Terrace, 8303-112 Street, Edmonton, AB, Canada T6G 2T4 \\ ${ }^{2}$ Epidemiology Program, Cancer Research Center of Hawaii, University of Hawaii, 1236 Laubala Street, Honolulu, \\ HI 96813, USA \\ (Submitted 23 February 2012 - Final revision received 8 June 2012 - Accepted 19 June 2012 - First published online 5 September 2012)
}

\section{Abstract}

Data are limited on how dietary sources of energy and nutrient intakes differ among ethnic groups in the USA. The objective of the present study was to characterise dietary sources of energy, total fat, saturated fat, protein, dietary fibre and added sugar for five ethnic groups. A validated quantitative FFQ was used to collect dietary data from 186916 men and women aged 45-75 years who were living in Hawaii and Los Angeles between 1993 and 1996. Participants represented five ethnic groups: African-American; Japanese-American; Native Hawaiian; Latino; Caucasian. The top ten dietary sources of energy contributed $36 \cdot 2-49 \cdot 6 \%$ to total energy consumption, with rice and bread contributing the most (11.4-27.8\%) across all ethnic-sex groups. Major dietary sources of total fat were chicken/turkey dishes and butter among most groups. Ice cream, ice milk or frozen yogurt contributed $4 \cdot 6-6 \cdot 2 \%$ to saturated fat intake across all ethnic-sex groups, except Latino-Mexico women. Chicken/turkey and bread were among the top dietary sources of protein (13.9-19.4\%). The top two sources of dietary fibre were bread and cereals (18.1-22\%) among all groups, except Latino-Mexico men. Regular sodas contributed the most to added sugar consumption. The present study provides, for the first time, data on the major dietary sources of energy, fat, saturated fat, protein, fibre and added sugar for these five ethnic groups in the USA. Such data are valuable for identifying target foods for nutritional intervention programmes and directing public health strategies aimed at reducing dietary risk factors for chronic disease.

Key words: Dietary sources: Nutrients: Ethnicity: Multiethnic Cohort

Cancer, CVD and diabetes ranked among the top ten causes of deaths in the USA in $2010^{(1)}$. Although chronic disease mortality has declined in recent years ${ }^{(2)}$, widespread prevalence of these diseases remains a critical public health concern. While genetic susceptibility plays an important role in the development of chronic disease, modifiable factors, such as diet, are key determinants ${ }^{(3)}$. Mokdad et al. ${ }^{(3)}$ attributed an estimated 400000 deaths in the USA in 2000 to poor diet and physical inactivity and projected more than 500000 deaths when the effects of overweight on mortality among the 1999-2000 estimates were realised. Substantial evidence supports that poor diet is a preventable risk factor for the development of numerous chronic diseases, and improving diet could result in a decrease in the incidence of and mortality from CVD, cancer and other diet-related chronic conditions $^{(3-7)}$.

The US Department of Agriculture (USDA), the American Heart Association, the National Cancer Institute and the American Diabetes Association advise the US population that meeting recommended nutrient intakes within energy requirements will help reduce the risk for a number of chronic diseases $^{(8-12)}$. Jointly developed by the US Department of Health and Human Services and the USDA, the Dietary Guidelines for Americans 2010 suggest following a healthful diet by consuming foods to meet nutrient needs in accordance with the Institute of Medicine recommendations ${ }^{(9)}$. Furthermore, the dietary guidelines recommend to keep the total fat intake between 20 and $35 \%$ of energy, consuming less than $10 \%$ of energy from saturated fat, selecting lean meat and poultry, and choosing carbohydrates, such as fibre-rich fruits, vegetables and whole grains as part of a healthful $\operatorname{diet}^{(9)}$.

To date, data are limited on dietary sources of energy, total fat, saturated fat, protein, dietary fibre and added sugar among minority ethnic/racial groups in the USA, including AfricanAmerican, Native Hawaiian, Japanese-American and Latino. Such data are necessary to illustrate how dietary consumption patterns vary between ethnic/racial groups and how these

Abbreviations: AfAm, African-American; CSFII, Continuing Surveys of Food Intakes by Individuals; JpAm, Japanese-American; MEC, Multiethnic Cohort; NH, Native Hawaiians; QFFQ, quantitative FFQ; USDA, US Department of Agriculture.

*Corresponding author: Dr S. Sharma, fax +1 780248 1611, email gita.sharma@ualberta.ca 
differences may be associated with chronic disease outcomes. Disproportionate rates of diet-related chronic diseases, such as obesity, are observed among minority ethnic/racial groups compared with Caucasian populations ${ }^{(13)}$, yet few large-scale studies have been attempted to identify dietary sources of energy and nutrients among different ethnic/racial groups, particularly minorities, in the USA.

The aim of the present study was to characterise the major dietary sources of energy, total fat, saturated fat, dietary fibre and added sugar among the main ethnic/racial groups in the Multiethnic Cohort (MEC). The present results intend to highlight similarities and differences in the types of foods that are consumed as well as the percentage contribution of dietary sources to total energy and selected nutrients by comparing intakes across all ethnic-sex groups represented in the study population.

\section{Methods}

The MEC was established in Hawaii and Los Angeles County, California to investigate the associations between diet and cancer among five ethnic/racial groups in the USA: AfricanAmericans (AfAm); Native Hawaiians (NH); JapaneseAmericans (JpAm); Latinos (born in Mexico and Central/ South America - Latino-Mexico; born in the USA - Latino-US); Caucasians. Study design, recruitment procedures and baseline characteristics have been reported elsewhere ${ }^{(14)}$. In brief, more than 215000 men and women aged 45-75years representing the five ethnic/racial groups were enrolled into the MEC study between 1993 and 1996. Ethnicity was self-defined.

Data were collected using a mailed self-administered questionnaire that was specifically developed for the MEC study $^{(14)}$. The twenty-six-page questionnaire included a seventeen-page quantitative FFQ (QFFQ) that collected data on the consumption of more than 180 food items over the past year. The QFFQ was developed from $3 \mathrm{~d}$ measured dietary records from sixty men and sixty women of each of the five ethnic/ racial groups ${ }^{(14,15)}$. Foods that contributed to more than $85 \%$ of the intake of fat, dietary fibre, vitamin A, carotenoids and vitamin $\mathrm{C}$ were listed on the QFFQ. Ethnic-specific foods were also included irrespective of their contribution to the diet. The QFFQ measured the amount of food consumed based on a choice of three portion sizes (represented in photographs) specific to each food item listed on the QFFQ and the usual intake frequency based on the categories ranging from 'never or hardly ever' to ' 2 or more times a day'. A sub-study was conducted to validate and calibrate the QFFQ using three repeated $24 \mathrm{~h}$ dietary recalls collected in each ethnic-sex group ${ }^{(15)}$. Average correlations for nutrient densities ranged from 0.57 to 0.74 across ethnic-sex strata, and those for specific nutrient groups were from 0.32 to 0.67 for proteins, 0.46 to 0.77 for total fat, 0.56 to 0.7 for saturated fats and 0.68 to 0.78 for fibre.

Energy and nutrient intakes were calculated based on all QFFQ items ${ }^{(16)}$; similar foods were combined to determine the percentage contribution of each source to the total daily intake of energy, total fat, saturated fat, protein, dietary fibre and added sugar. Participants excluded in the analysis were those with extreme mean energy intake (beyond 3 SD) and/ or macronutrient intake (beyond $3.5 \mathrm{sD}$ ). As the focus of the present study was to examine nutrient sources among persons of different ethnicities, those who identified themselves being from a mixed ethnic background were also excluded. Latinos born in the Caribbean were also excluded due to the very small number of participants. A total of 186916 participants were included in the present analysis.

The present study was conducted according to the guidelines laid down in the Declaration of Helsinki, and the protocol was approved by the Institutional Review Boards of the University of Hawaii and the University of Southern California.

\section{Results}

Table 1 displays the demographic information of the participants enrolled in the MEC. NH men and AfAm women had the highest average BMI among all ethnic-sex groups, while

Table 1. Demographic information, BMI and daily energy intake of the participants* (Mean values and standard deviations)

\begin{tabular}{|c|c|c|c|c|c|c|c|c|c|c|c|c|}
\hline & \multicolumn{2}{|c|}{ AfAm } & \multicolumn{2}{|c|}{$\mathrm{NH}$} & \multicolumn{2}{|c|}{$\mathrm{JpAm}$} & \multicolumn{2}{|c|}{ Latinos-Mexico } & \multicolumn{2}{|c|}{ Latinos-US } & \multicolumn{2}{|c|}{ Caucasian } \\
\hline & Mean & SD & Mean & SD & Mean & SD & Mean & SD & Mean & SD & Mean & SD \\
\hline \multicolumn{13}{|l|}{ Men } \\
\hline$n$ & \multicolumn{2}{|c|}{11722} & \multicolumn{2}{|c|}{5979} & \multicolumn{2}{|c|}{25893} & \multicolumn{2}{|c|}{10180} & \multicolumn{2}{|c|}{10613} & \multicolumn{2}{|c|}{21933} \\
\hline Age (years) & 62 & 8.9 & 57 & 8.7 & 61 & $9 \cdot 2$ & 59 & $7 \cdot 7$ & 61 & $7 \cdot 6$ & 59 & $9 \cdot 1$ \\
\hline BMI $\left(\mathrm{kg} / \mathrm{m}^{2}\right)$ & $26 \cdot 7$ & $4 \cdot 3$ & 28.5 & $5 \cdot 1$ & $24 \cdot 7$ & 3.3 & $26 \cdot 7$ & 3.7 & $26 \cdot 7$ & $4 \cdot 1$ & $26 \cdot 0$ & 4.0 \\
\hline \multicolumn{13}{|l|}{ Energy } \\
\hline $\mathrm{kcal} / \mathrm{d}$ & 2194 & 1166 & 2760 & 1311 & 2255 & 833 & 2716 & 1401 & 2468 & 1261 & 2283 & 899 \\
\hline $\mathrm{kJ} / \mathrm{d}$ & 9180 & 4879 & 11548 & 5485 & 9435 & 3485 & 11364 & 5862 & 10326 & 5276 & 9552 & 3761 \\
\hline \multicolumn{13}{|l|}{ Women } \\
\hline$n$ & \multicolumn{2}{|c|}{20130} & \multicolumn{2}{|c|}{7650} & \multicolumn{2}{|c|}{25355} & \multicolumn{2}{|c|}{10903} & \multicolumn{2}{|c|}{11255} & \multicolumn{2}{|c|}{25303} \\
\hline Age (years) & 61 & $9 \cdot 0$ & 56 & 8.7 & 61 & 8.9 & 58 & $7 \cdot 6$ & 60 & $7 \cdot 9$ & 59 & $9 \cdot 0$ \\
\hline $\operatorname{BMI}\left(\mathrm{kg} / \mathrm{m}^{2}\right)$ & $28 \cdot 4$ & $5 \cdot 8$ & $28 \cdot 0$ & $6 \cdot 1$ & $23 \cdot 1$ & $3 \cdot 8$ & $27 \cdot 0$ & 4.8 & $27 \cdot 6$ & $5 \cdot 4$ & $25 \cdot 2$ & $5 \cdot 2$ \\
\hline \multicolumn{13}{|l|}{ Energy } \\
\hline $\mathrm{kcal} / \mathrm{d}$ & 1879 & 993 & 2370 & 1263 & 1808 & 678 & 2316 & 1238 & 2056 & 1104 & 1805 & 703 \\
\hline $\mathrm{kJ} / \mathrm{d}$ & 7892 & 4155 & 9916 & 5284 & 7565 & 2837 & 9690 & 5180 & 8602 & 4619 & 7552 & 2941 \\
\hline
\end{tabular}

AfAm, African-American; NH, Native Hawaiian; JpAm, Japanese-American.

${ }^{*}$ Participants in the Multiethnic Cohort Study in Hawaii and Los Angeles. 
Table 2. Ten major sources of 'energy' and the percentage (\%) contribution of each item in each ethnic-sex group*

\begin{tabular}{|c|c|c|c|c|c|c|c|c|c|c|c|c|}
\hline & \multicolumn{2}{|l|}{ AfAm } & \multicolumn{2}{|l|}{$\mathrm{NH}$} & \multicolumn{2}{|l|}{ JpAm } & \multicolumn{2}{|c|}{ Latinos-Mexico } & \multicolumn{2}{|c|}{ Latinos-US } & \multicolumn{2}{|c|}{ Caucasian } \\
\hline & Food items & $\begin{array}{l}\% \text { Contri- } \\
\text { bution }\end{array}$ & Foods items & $\begin{array}{l}\% \text { Contri- } \\
\text { bution }\end{array}$ & Foods items & $\begin{array}{l}\% \text { Contri- } \\
\text { bution }\end{array}$ & Foods items & $\begin{array}{l}\% \text { Contri- } \\
\text { bution }\end{array}$ & Foods items & $\begin{array}{l}\% \text { Contri- } \\
\text { bution }\end{array}$ & Foods items & $\begin{array}{l}\% \text { Contri- } \\
\text { bution }\end{array}$ \\
\hline \multirow[t]{10}{*}{ Men } & Rice & $8 \cdot 1$ & Rice & $15 \cdot 8$ & Rice & 22.9 & Bread & $9 \cdot 0$ & Rice & 14.4 & Bread & 6.5 \\
\hline & Bread & 6.4 & Bread & 5.4 & Bread & 4.9 & Rice & 7.7 & Bread & $6 \cdot 1$ & Rice & 6.4 \\
\hline & $\begin{array}{l}\text { Chicken or turkey } \\
\text { dishes }\end{array}$ & 4.6 & Beer & 4.4 & Beer & 4.4 & $\begin{array}{l}\text { Muffins or } \\
\text { doughnuts }\end{array}$ & $4 \cdot 1$ & Beer & $4 \cdot 2$ & $\begin{array}{l}\text { Pasta with tomato } \\
\text { sauce or cheese }\end{array}$ & $4 \cdot 6$ \\
\hline & Regular sodas & 3.8 & Regular sodas & 3.3 & $\begin{array}{l}\text { Chicken or turkey } \\
\text { dishes }\end{array}$ & 3.3 & Taco salad & 3.9 & $\begin{array}{l}\text { Chicken or turkey } \\
\text { dishes }\end{array}$ & 3.5 & Beer & 4.5 \\
\hline & $\begin{array}{l}\text { Pasta with tomato } \\
\text { sauce or cheese }\end{array}$ & 3.5 & $\begin{array}{l}\text { Chicken or turkey } \\
\text { dishes }\end{array}$ & 3.0 & Fish & 2.6 & Cookies or cakes & 3.3 & $\begin{array}{l}\text { Pasta with tomato } \\
\text { sauce or cheese }\end{array}$ & 3.1 & Cereals & 3.6 \\
\hline & Cereals & 3.4 & Fish & $2 \cdot 6$ & Cereals & 2.6 & $\begin{array}{l}\text { Crackers, chips or } \\
\text { popcorn }\end{array}$ & $3 \cdot 1$ & Regular sodas & 2.8 & $\begin{array}{l}\text { Chicken or turkey } \\
\text { dishes }\end{array}$ & 2.9 \\
\hline & $\begin{array}{l}\text { Orange, grapefruit } \\
\text { or pomelo }\end{array}$ & 3.1 & $\begin{array}{l}\text { Burgers, meatballs } \\
\text { or patties }\end{array}$ & 2.6 & Regular sodas & $2 \cdot 3$ & $\begin{array}{l}\text { Chicken or turkey } \\
\text { dishes }\end{array}$ & 2.9 & Cereals & $2 \cdot 7$ & $\begin{array}{l}\text { Crackers, chips or } \\
\text { popcorn }\end{array}$ & 2.8 \\
\hline & Beer & $3 \cdot 1$ & Cereals & $2 \cdot 3$ & $\begin{array}{l}\text { Pasta with tomato } \\
\text { sauce or cheese }\end{array}$ & $2 \cdot 3$ & $\begin{array}{l}\text { Ice cream, ice milk } \\
\text { or frozen yogurt }\end{array}$ & $2 \cdot 2$ & $\begin{array}{l}\text { Burgers, meatballs } \\
\text { or patties }\end{array}$ & 2.6 & $\begin{array}{l}\text { Burgers, meatballs } \\
\text { or patties }\end{array}$ & $2 \cdot 7$ \\
\hline & $\begin{array}{l}\text { Burgers, meatballs } \\
\text { or patties }\end{array}$ & 3.1 & $\begin{array}{l}\text { Pasta with tomato } \\
\text { sauce or cheese }\end{array}$ & $2 \cdot 3$ & $\begin{array}{l}\text { Orange, grapefruit } \\
\text { or pomelo }\end{array}$ & $2 \cdot 2$ & Regular sodas & $2 \cdot 2$ & $\begin{array}{l}\text { Ice cream, ice milk } \\
\text { or frozen yogurt }\end{array}$ & $2 \cdot 1$ & Regular sodas & $2 \cdot 7$ \\
\hline & $\begin{array}{l}\text { Crackers, chips or } \\
\text { popcorn }\end{array}$ & $2 \cdot 6$ & $\begin{array}{l}\text { Ice cream, ice milk } \\
\text { or frozen yogurt }\end{array}$ & $2 \cdot 1$ & $\begin{array}{l}\text { Stir-fried meat and } \\
\text { vegetables }\end{array}$ & $2 \cdot 1$ & $\begin{array}{l}\text { Pasta with tomato } \\
\text { sauce or cheese }\end{array}$ & $2 \cdot 2$ & $\begin{array}{l}\text { Orange, grapefruit } \\
\text { or pomelo }\end{array}$ & $2 \cdot 1$ & $\begin{array}{l}\text { Ice cream, ice milk } \\
\text { or frozen yogurt }\end{array}$ & 2.4 \\
\hline Total (\%) & & 41.7 & & 43.8 & & $49 \cdot 6$ & & $40 \cdot 6$ & & $43 \cdot 6$ & & 39.1 \\
\hline \multirow[t]{10}{*}{ Women } & Bread & 6.4 & Rice & $11 \cdot 8$ & Rice & $19 \cdot 0$ & Rice & $5 \cdot 7$ & Rice & 11.8 & Bread & 7.9 \\
\hline & Rice & 6.0 & Bread & 6.2 & Bread & 6.2 & Bread & 5.7 & Bread & 7.2 & Rice & $5 \cdot 3$ \\
\hline & $\begin{array}{l}\text { Chicken or turkey } \\
\text { dishes }\end{array}$ & 4.7 & $\begin{array}{l}\text { Pasta with tomato } \\
\text { sauce or cheese }\end{array}$ & 3.0 & Cereals & 3.3 & Cereals & 4.7 & $\begin{array}{l}\text { Pasta with tomato } \\
\text { sauce or cheese }\end{array}$ & 3.8 & $\begin{array}{l}\text { Pasta with tomato } \\
\text { sauce or cheese }\end{array}$ & $5 \cdot 1$ \\
\hline & $\begin{array}{l}\text { Pasta with tomato } \\
\text { sauce or cheese }\end{array}$ & 4.4 & Regular sodas & 3.0 & $\begin{array}{l}\text { Orange, grapefruit } \\
\text { or pomelo }\end{array}$ & $3 \cdot 2$ & $\begin{array}{l}\text { Chicken or turkey } \\
\text { dishes }\end{array}$ & 3.8 & Cereals & 3.4 & Cereals & 3.9 \\
\hline & $\begin{array}{l}\text { Crackers, chips or } \\
\text { popcorn }\end{array}$ & 4.0 & $\begin{array}{l}\text { Chicken or turkey } \\
\text { dishes }\end{array}$ & 3.0 & $\begin{array}{l}\text { Chicken or turkey } \\
\text { dishes }\end{array}$ & 3.0 & $\begin{array}{l}\text { Pasta with tomato } \\
\text { sauce or cheese }\end{array}$ & 3.5 & $\begin{array}{l}\text { Chicken or turkey } \\
\text { dishes }\end{array}$ & 3.4 & $\begin{array}{l}\text { Chicken or turkey } \\
\text { dishes }\end{array}$ & 2.9 \\
\hline & Cereals & 3.8 & Cereals & 3.0 & $\begin{array}{l}\text { Pasta with tomato } \\
\text { sauce or cheese }\end{array}$ & 2.8 & Bananas & 3.4 & $\begin{array}{l}\text { Orange, grapefruit } \\
\text { or pomelo }\end{array}$ & $2 \cdot 6$ & $\begin{array}{l}\text { Crackers, chips or } \\
\text { popcorn }\end{array}$ & 2.9 \\
\hline & $\begin{array}{l}\text { Orange, grapefruit } \\
\text { or pomelo }\end{array}$ & 3.0 & $\begin{array}{l}\text { Orange, grapefruit } \\
\text { or pomelo }\end{array}$ & 2.5 & $\begin{array}{l}\text { Stir-fried meat and } \\
\text { vegetables }\end{array}$ & 2.6 & $\begin{array}{l}\text { Orange, grapefruit } \\
\text { or pomelo }\end{array}$ & 3.1 & $\begin{array}{l}\text { Crackers, chips or } \\
\text { popcorn }\end{array}$ & $2 \cdot 4$ & $\begin{array}{l}\text { Orange, grapefruit } \\
\text { or pomelo }\end{array}$ & $2 \cdot 7$ \\
\hline & $\begin{array}{l}\text { Ice cream, ice milk } \\
\text { or frozen yogurt }\end{array}$ & 2.5 & Fish & 2.5 & Bananas & 2.5 & Pizza & $2 \cdot 2$ & Bananas & $2 \cdot 3$ & Bananas & $2 \cdot 4$ \\
\hline & Cookies or cakes & $2 \cdot 3$ & $\begin{array}{l}\text { Burgers, meatballs } \\
\text { or patties }\end{array}$ & 2.4 & Fish & 2.5 & Low-fat milk & $2 \cdot 1$ & Regular sodas & $2 \cdot 3$ & Cookies or cakes & $2 \cdot 1$ \\
\hline & Bananas & $2 \cdot 2$ & $\begin{array}{l}\text { Crackers, chips or } \\
\text { popcorn }\end{array}$ & $2 \cdot 0$ & $\begin{array}{l}\text { Peanuts or other } \\
\text { nuts }\end{array}$ & 1.9 & $\begin{array}{l}\text { Muffins or } \\
\text { doughnuts }\end{array}$ & $2 \cdot 0$ & $\begin{array}{l}\text { Stir-fried meat and } \\
\text { vegetables }\end{array}$ & $2 \cdot 0$ & $\begin{array}{l}\text { Ice cream, ice milk } \\
\text { or frozen yogurt }\end{array}$ & $2 \cdot 1$ \\
\hline Total (\%) & & 39.3 & & 39.4 & & $47 \cdot 0$ & & $36 \cdot 2$ & & $41 \cdot 2$ & & 37.3 \\
\hline
\end{tabular}

AfAm, African-American; NH, Native Hawaiian; JpAm, Japanese-American.

* Participants in the Multiethnic Cohort Study in Hawaii and Los Angeles. 
$\mathrm{NH}$ men and $\mathrm{NH}$ women reported the highest mean daily energy intakes.

The top ten dietary sources of energy contributed from $36 \cdot 2 \%$ (Latino-Mexico women) to $49 \cdot 6 \%$ (JpAm men) to total energy intake (Table 2). Across all ethnic-sex groups, the dietary sources of energy intake were similar with rice and bread contributing most, ranging from $11.4 \%$ (Latino-Mexico women) to $27 \cdot 8 \%$ (JpAm men). However, the percentages of contribution of each source varied among the ethnic-sex groups. Chicken/turkey dishes and pasta with tomato sauce or cheese were in the top ten list for all groups. Cereal was among the top contributors to energy for all ethnic-sex groups (2.3-4.7\%), except Latino-Mexico men. Regular soda contributed between $2 \cdot 2 \%$ (Latino-Mexico men) and 3.8\% (AfAm men) to total energy intake. Interestingly, beer was a major source of energy intake among men of all ethnic/racial groups with the exception of Latino-Mexico; conversely, beer did not appear among the ten major sources of energy for women of any of the ethnic/racial groups.

The ten major dietary sources of fat are presented in Table 3 for all ethnic-sex groups. The top ten sources of total fat contributed $35.1 \%$ (Latino-Mexico women) to $43 \%$ (JpAm men) of total fat intake (Table 3). A top-three food source of fat across all ethnic-sex groups, chicken/turkey dishes, contributed from $4 \cdot 1 \%$ (Caucasian women) to $7 \cdot 4 \%$ (AfAm men) to total fat intake. Butter was a top-five food source among all groups except Latino-Mexico men, contributing between 3.6\% (Latino-Mexico women) and $6.2 \%$ (NH women). Peanuts/other nuts also appeared among the top five major sources for men and women in four of the ethnic/racial groups (AfAm, NH, JpAm and Latino-US); the percentage contribution to total fat intake ranged from $4 \%$ for Latino-US men to $5.9 \%$ for JpAm men.

The sources of saturated fats are shown in Table 4. Ice cream, ice milk or frozen yogurt was among the top five contributors to total saturated fat intake for all groups, except Latino-Mexico women. Butter, likewise, was a significant food source of saturated fat for all but Latino-Mexico men, contributing from $4.4 \%$ among Latino-Mexico women to 7 and $7 \cdot 2 \%$ for $\mathrm{NH}$ men and women, respectively.

Chicken/turkey dishes were a major contributor to total protein intake across all ethnic-sex groups, topping the list for men and women in four of the ethnic/racial groups (AfAm, NH, Latino-Mexico and Latino-US; Table 5). The first dietary source of protein for JpAm men and women was rice, contributing $12 \cdot 7$ and $10.4 \%$ to protein intake, respectively. Fish was also among the top five major sources in four ethnic/racial groups (AfAm, NH, JpAm and Latino-US); the percentage contribution varied from $4.8 \%$ for AfAm men to $7.7 \%$ for JpAm men. Bread contributed from $4.6 \%$ (Latino-Mexico women) to $7 \cdot 6 \%$ (Latino-Mexico men) to total protein intake and also appeared among the top five sources across all ethnic-sex groups.

Bread and cereals were the top two food sources of dietary fibre among all groups, except Latino-Mexico men, for whom beans replaced cereals as the second highest contributor (Table 6). Together, bread and cereals accounted for $18.1 \%$
(NH women) to $22 \%$ (Caucasian men). Other important dietary sources of fibre were orange, grapefruit or pomelo across all ethnic-sex groups and bananas for men and women in all groups, except AfAm. Regular sodas were the top contributor to added sugar intake, ranging from $17 \cdot 5 \%$ for JpAm women to $35.2 \%$ for Latino-Mexico men to total consumption (Table 7). The percentage contribution of regular sodas alone is greater than that of the other four major food sources combined for all groups except JpAm and Caucasian women. Other fruit juices/drinks were also a major source of added sugar across all ethnic-sex groups.

\section{Discussion}

The present study describes similarities and differences between ethnic/racial groups both in the types of foods that are consumed as well as the percentage contribution of these food sources to total energy and specific nutrient intake. In the present study population, we identified rice, bread, chicken/turkey dishes, sodas and pasta/tomato sauce dishes as the five major sources of energy. In contrast, Cotton et $a l .{ }^{(17)}$ identified 'yeast bread', 'beef', 'cakes/ cookies/quick breads/doughnuts', 'soft drinks/soda' and 'milk' as the top five contributors to total energy intake among US adults from 1994 to $1996^{(18)}$. The differences may be attributed to several factors, including the use of different dietary assessment instruments and different sampling methodologies. Cotton et al. analysed $24 \mathrm{~h}$ dietary recalls collected as part of the Continuing Surveys of Food Intakes by Individuals (CSFII), whereas the present study utilised a validated QFFQ that was specifically developed to characterise the dietary consumption patterns of our multiethnic study population. Furthermore, the CSFII used personal weighting factors to compensate for demographic differences between the sampled population and the US population in order to obtain a nationally representative sample ${ }^{(18)}$. By contrast, the present study population comprises the diverse ethnic/racial groups of Hawaii and Los Angeles County, and requires no personal weighting factors to achieve the targeted population sample.

Consumption patterns in the USA have evolved as diverse population groups introduce new foods, novel products appear on the market, and diet trends emerge and fade. The US Department of Health and Human Services and the USDA Dietary Guidelines for Americans 2010 are designed to help Americans make better food choices to promote health and to reduce the risk for chronic diseases ${ }^{(9)}$. While the dietary guidelines contain technical information intended for policymakers, educators, dietitians and other health practitioners, the recommendations are ultimately targeted for the general public to embrace a healthier pattern of eating. The present findings, therefore, may serve to assist nutrition professionals in identifying foods for intervention and translating the dietary guidelines for practical application for specific ethnic/racial minority groups.

The percentage of the US population claiming minority racial or ethnic heritage is growing ${ }^{(19,20)}$. The US population is becoming increasingly diverse with the nation's minority 
Table 3. Ten major sources of 'total fat' and the percentage (\%) contribution of each item in each ethnic-sex group*

\begin{tabular}{|c|c|c|c|c|c|c|c|c|c|c|c|c|}
\hline & \multicolumn{2}{|l|}{ AfAm } & \multicolumn{2}{|l|}{$\mathrm{NH}$} & \multicolumn{2}{|l|}{$\mathrm{JpAm}$} & \multicolumn{2}{|c|}{ Latinos-Mexico } & \multicolumn{2}{|c|}{ Latinos-US } & \multicolumn{2}{|c|}{ Caucasian } \\
\hline & Food items & $\begin{array}{l}\% \text { Contri- } \\
\text { bution }\end{array}$ & Foods items & $\begin{array}{l}\% \text { Contri- } \\
\text { bution }\end{array}$ & Foods items & $\begin{array}{l}\% \text { Contri- } \\
\text { bution }\end{array}$ & Foods items & $\begin{array}{l}\% \text { Contri- } \\
\text { bution }\end{array}$ & Foods items & $\begin{array}{l}\% \text { Contri- } \\
\text { bution }\end{array}$ & Foods items & $\begin{array}{l}\% \text { Contri- } \\
\text { bution }\end{array}$ \\
\hline \multirow[t]{10}{*}{ Men } & $\begin{array}{l}\text { Chicken or turkey } \\
\text { dishes }\end{array}$ & 7.4 & Butter & 5.8 & $\begin{array}{l}\text { Chicken or turkey } \\
\text { dishes }\end{array}$ & 6.0 & Taco salad & 5.8 & $\begin{array}{l}\text { Chicken or turkey } \\
\text { dishes }\end{array}$ & $5 \cdot 8$ & $\begin{array}{l}\text { Peanuts or other } \\
\text { nuts }\end{array}$ & 5.6 \\
\hline & $\begin{array}{l}\text { Peanuts or other } \\
\text { nuts }\end{array}$ & $5 \cdot 0$ & $\begin{array}{l}\text { Chicken or turkey } \\
\text { dishes }\end{array}$ & $5 \cdot 1$ & $\begin{array}{l}\text { Peanuts or other } \\
\text { nuts }\end{array}$ & 5.9 & $\begin{array}{l}\text { Muffins or } \\
\text { doughnuts }\end{array}$ & 4.8 & Butter & 4.5 & $\begin{array}{l}\text { Pasta with tomato } \\
\text { sauce or cheese }\end{array}$ & 5.5 \\
\hline & $\begin{array}{l}\text { Burgers, meatballs } \\
\text { or patties }\end{array}$ & 4.5 & $\begin{array}{l}\text { Peanuts or other } \\
\text { nuts }\end{array}$ & 4.5 & Fish & 4.8 & $\begin{array}{l}\text { Chicken or turkey } \\
\text { dishes }\end{array}$ & 4.6 & $\begin{array}{l}\text { Peanuts or other } \\
\text { nuts }\end{array}$ & 4.0 & Butter & $5 \cdot 2$ \\
\hline & Butter & 4.5 & Fish & $4 \cdot 3$ & $\begin{array}{l}\text { Regular salad } \\
\text { dressing }\end{array}$ & 4.4 & $\begin{array}{l}\text { Crackers, chips or } \\
\text { popcorn }\end{array}$ & 4.4 & $\begin{array}{l}\text { Burgers, meatballs } \\
\text { or patties }\end{array}$ & 3.8 & $\begin{array}{l}\text { Chicken or turkey } \\
\text { dishes }\end{array}$ & 4.4 \\
\hline & $\begin{array}{l}\text { Pasta with tomato } \\
\text { sauce or cheese }\end{array}$ & 4.3 & $\begin{array}{l}\text { Burgers, meatballs } \\
\text { or patties }\end{array}$ & 3.8 & Butter & 4.1 & Bread & 4.1 & $\begin{array}{l}\text { Pasta with tomato } \\
\text { sauce or cheese }\end{array}$ & 3.7 & $\begin{array}{l}\text { Burgers, meatballs } \\
\text { or patties }\end{array}$ & 3.9 \\
\hline & Pork and ham & 3.7 & Beef and lamb & 3.7 & Oil & 4.0 & Cookies or cakes & 3.7 & Spam or bologna & 3.6 & $\begin{array}{l}\text { Crackers, chips or } \\
\text { popcorn }\end{array}$ & 3.7 \\
\hline & Spam or bologna & 3.6 & Spam or bologna & 3.7 & $\begin{array}{l}\text { Stir-fried meat and } \\
\text { vegetables }\end{array}$ & 3.7 & Beef and lamb & 3.5 & Beef and lamb & 3.5 & Salad dressing & 3.7 \\
\hline & $\begin{array}{l}\text { Crackers, chips or } \\
\text { popcorn }\end{array}$ & 3.4 & Pork and ham & 3.6 & Spam or bologna & 3.5 & Cheese & 3.4 & Fish & 3.4 & Bread & $3 \cdot 2$ \\
\hline & Bread & $3 \cdot 2$ & Oil & 3.5 & $\begin{array}{l}\text { Burgers, meatballs } \\
\text { or patties }\end{array}$ & 3.4 & Salad dressing & 3.3 & Pork and ham & 3.2 & Cheese & $3 \cdot 1$ \\
\hline & Fish & 2.9 & Salad dressing & 3.3 & Beef and lamb & 3.2 & Butter & $3 \cdot 1$ & Bread & $3 \cdot 1$ & Ice cream & 3.0 \\
\hline Total (\%) & & 42.5 & & $41 \cdot 3$ & & 43.0 & & $40 \cdot 7$ & & 38.6 & & $41 \cdot 3$ \\
\hline \multirow[t]{10}{*}{ Women } & $\begin{array}{l}\text { Chicken or turkey } \\
\text { dishes }\end{array}$ & $7 \cdot 3$ & Butter & $6 \cdot 2$ & $\begin{array}{l}\text { Peanuts or other } \\
\text { nuts }\end{array}$ & 5.4 & $\begin{array}{l}\text { Chicken or turkey } \\
\text { dishes }\end{array}$ & 5.4 & Butter & 5.4 & $\begin{array}{l}\text { Pasta with tomato } \\
\text { sauce or cheese }\end{array}$ & $6 \cdot 2$ \\
\hline & $\begin{array}{l}\text { Pasta with tomato } \\
\text { sauce or cheese }\end{array}$ & $5 \cdot 2$ & $\begin{array}{l}\text { Chicken or turkey } \\
\text { dishes }\end{array}$ & 4.7 & $\begin{array}{l}\text { Regular salad } \\
\text { dressing }\end{array}$ & $5 \cdot 2$ & $\begin{array}{l}\text { Pasta with tomato } \\
\text { sauce or cheese }\end{array}$ & 4.1 & $\begin{array}{l}\text { Chicken or turkey } \\
\text { dishes }\end{array}$ & 5.4 & Butter & $5 \cdot 8$ \\
\hline & $\begin{array}{l}\text { Crackers, chips or } \\
\text { popcorn }\end{array}$ & $5 \cdot 0$ & Fish & $4 \cdot 2$ & $\begin{array}{l}\text { Chicken or turkey } \\
\text { dishes }\end{array}$ & 4.9 & Butter & 3.6 & $\begin{array}{l}\text { Pasta with tomato } \\
\text { sauce or cheese }\end{array}$ & 4.7 & $\begin{array}{l}\text { Peanuts or other } \\
\text { nuts }\end{array}$ & $4 \cdot 5$ \\
\hline & $\begin{array}{l}\text { Peanuts or other } \\
\text { nuts }\end{array}$ & 4.8 & $\begin{array}{l}\text { Peanuts or other } \\
\text { nuts }\end{array}$ & $4 \cdot 1$ & Butter & $4 \cdot 8$ & $\begin{array}{l}\text { Regular salad } \\
\text { dressing }\end{array}$ & 3.5 & $\begin{array}{l}\text { Peanuts or other } \\
\text { nuts }\end{array}$ & $4 \cdot 1$ & $\begin{array}{l}\text { Chicken or turkey } \\
\text { dishes }\end{array}$ & $4 \cdot 1$ \\
\hline & Butter & 4.7 & $\begin{array}{l}\text { Regular salad } \\
\text { dressing }\end{array}$ & 3.7 & Fish & 4.5 & Taco salad & 3.3 & Bread & 3.7 & Bread & 4.1 \\
\hline & Fish & $3 \cdot 2$ & $\begin{array}{l}\text { Pasta with tomato } \\
\text { sauce or cheese }\end{array}$ & 3.6 & $\begin{array}{l}\text { Stir-fried meat and } \\
\text { vegetables }\end{array}$ & 4.5 & Cheese & 3.3 & Fish & 3.5 & Salad dressing & 4.0 \\
\hline & Bread & $3 \cdot 2$ & $\begin{array}{l}\text { Burgers, meatballs } \\
\text { or patties }\end{array}$ & 3.5 & Oil & 4.0 & Pork and ham & 3.2 & $\begin{array}{l}\text { Stir-fried meat and } \\
\text { vegetables }\end{array}$ & 3.3 & $\begin{array}{l}\text { Crackers, chips or } \\
\text { popcorn }\end{array}$ & 3.9 \\
\hline & Ice cream & 3.0 & Oil & $3 \cdot 2$ & $\begin{array}{l}\text { Pasta with tomato } \\
\text { sauce or cheese }\end{array}$ & 3.5 & Pizza & 3.0 & Salad dressing & $3 \cdot 2$ & Cheese & 3.6 \\
\hline & $\begin{array}{l}\text { Stir-fried meat and } \\
\text { vegetables }\end{array}$ & $2 \cdot 9$ & Bread & $3 \cdot 1$ & Bread & 3.4 & $\begin{array}{l}\text { Burgers, meatballs } \\
\text { or patties }\end{array}$ & 3.0 & $\begin{array}{l}\text { Crackers, chips or } \\
\text { popcorn }\end{array}$ & 3.2 & Fish & $3 \cdot 1$ \\
\hline & Pork and ham & $2 \cdot 9$ & Spam or bologna & 3.1 & Rice & $2 \cdot 7$ & Bread & $2 \cdot 7$ & $\begin{array}{l}\text { Burgers, meatballs } \\
\text { or patties }\end{array}$ & $2 \cdot 8$ & Cookies or cakes & $2 \cdot 8$ \\
\hline Total (\%) & & $42 \cdot 2$ & & 39.4 & & $42 \cdot 9$ & & $35 \cdot 1$ & & $39 \cdot 3$ & & $42 \cdot 1$ \\
\hline
\end{tabular}

AfAm, African-American; NH, Native Hawaiian; JpAm, Japanese-American

Participants in the Multiethnic Cohort Study in Hawaii and Los Angeles. 
Table 4. Ten major sources of 'saturated fat' and the percentage (\%) contribution of each item in each ethnic-sex group*

\begin{tabular}{|c|c|c|c|c|c|c|c|c|c|c|c|c|}
\hline & \multicolumn{2}{|l|}{ AfAm } & \multicolumn{2}{|l|}{$\mathrm{NH}$} & \multicolumn{2}{|l|}{ JpAm } & \multicolumn{2}{|c|}{ Latinos-Mexico } & \multicolumn{2}{|c|}{ Latinos-US } & \multicolumn{2}{|c|}{ Caucasian } \\
\hline & Food items & $\begin{array}{l}\% \text { Contri- } \\
\text { bution }\end{array}$ & Foods items & $\begin{array}{l}\% \text { Contri- } \\
\text { bution }\end{array}$ & Foods items & $\begin{array}{l}\% \text { Contri- } \\
\text { bution }\end{array}$ & Foods items & $\begin{array}{l}\% \text { Contri- } \\
\text { bution }\end{array}$ & Foods items & $\begin{array}{l}\% \text { Contri- } \\
\text { bution }\end{array}$ & Foods items & $\begin{array}{l}\% \text { Contri- } \\
\text { bution }\end{array}$ \\
\hline \multirow[t]{10}{*}{ Men } & $\begin{array}{l}\text { Ice cream, ice milk } \\
\text { or frozen yogurt }\end{array}$ & 5.9 & Butter & 7.0 & $\begin{array}{l}\text { Ice cream, ice milk } \\
\text { or frozen yogurt }\end{array}$ & $5 \cdot 3$ & Cheese & 6.9 & $\begin{array}{l}\text { Ice cream, ice milk } \\
\text { or frozen yogurt }\end{array}$ & $6 \cdot 2$ & $\begin{array}{l}\text { Pasta with tomato } \\
\text { sauce or cheese }\end{array}$ & 6.6 \\
\hline & $\begin{array}{l}\text { Chicken or turkey } \\
\text { dishes }\end{array}$ & $5 \cdot 8$ & $\begin{array}{l}\text { Ice cream, ice milk } \\
\text { or frozen yogurt }\end{array}$ & $6 \cdot 2$ & $\begin{array}{l}\text { Chicken or turkey } \\
\text { dishes }\end{array}$ & 5.0 & Taco salad & $6 \cdot 1$ & Butter & $5 \cdot 1$ & Cheese & 6.5 \\
\hline & $\begin{array}{l}\text { Burgers, meatballs } \\
\text { or patties }\end{array}$ & $5 \cdot 7$ & Beef and lamb & 5.0 & $\begin{array}{l}\text { Burgers, meatballs } \\
\text { or patties }\end{array}$ & 4.7 & $\begin{array}{l}\text { Ice cream, ice milk } \\
\text { or frozen yogurt }\end{array}$ & $5 \cdot 7$ & $\begin{array}{l}\text { Burgers, meatballs } \\
\text { or patties }\end{array}$ & 4.8 & $\begin{array}{l}\text { Ice cream, ice milk } \\
\text { or frozen yogurt }\end{array}$ & $6 \cdot 2$ \\
\hline & $\begin{array}{l}\text { Pasta with tomato } \\
\text { sauce or cheese }\end{array}$ & $5 \cdot 4$ & $\begin{array}{l}\text { Burgers, meatballs } \\
\text { or patties }\end{array}$ & 4.9 & Beef and lamb & 4.7 & Beef and lamb & 4.5 & Beef and lamb & 4.6 & Butter & $5 \cdot 8$ \\
\hline & Butter & 4.6 & Spam or bologna & 4.6 & Spam or bologna & 4.6 & $\begin{array}{l}\text { Muffins or dough- } \\
\text { nuts }\end{array}$ & 3.9 & $\begin{array}{l}\text { Chicken or turkey } \\
\text { dishes }\end{array}$ & 4.5 & $\begin{array}{l}\text { Burgers, meatballs } \\
\text { or patties }\end{array}$ & 4.9 \\
\hline & Pork and ham & 4.6 & Pork and ham & 4.4 & Butter & 4.5 & $\begin{array}{l}\text { Chicken or turkey } \\
\text { dishes }\end{array}$ & 3.3 & $\begin{array}{l}\text { Pasta with tomato } \\
\text { sauce or cheese }\end{array}$ & 4.5 & Beef and lamb & 3.5 \\
\hline & Cheese & 4.5 & $\begin{array}{l}\text { Chicken or turkey } \\
\text { dishes }\end{array}$ & 4.0 & Meat soups or stew & 3.9 & Cookies or cakes & 3.3 & Spam or bologna & 4.4 & $\begin{array}{l}\text { Chicken or turkey } \\
\text { dishes }\end{array}$ & 3.4 \\
\hline & Spam or bologna & 4.5 & $\begin{array}{l}\text { Pasta with tomato } \\
\text { sauce or cheese }\end{array}$ & 3.4 & Pork and ham & 3.8 & Meat burritos & 3.3 & Cheese & $4 \cdot 2$ & Spam or bologna & 3.3 \\
\hline & Beef and lamb & 3.4 & Meat soups or stew & $3 \cdot 2$ & $\begin{array}{l}\text { Pasta with tomato } \\
\text { sauce or cheese }\end{array}$ & 3.7 & Butter & $3 \cdot 2$ & Pork and ham & 3.9 & Low-fat milk & $3 \cdot 2$ \\
\hline & Low-fat milk & $2 \cdot 6$ & Cheese & 2.6 & $\begin{array}{l}\text { Stir-fried meat and } \\
\text { vegetables }\end{array}$ & 3.5 & $\begin{array}{l}\text { Crackers, chips or } \\
\text { popcorn }\end{array}$ & $3 \cdot 2$ & Meat soups or stew & $3 \cdot 1$ & Pork and ham & 2.9 \\
\hline Total (\%) & & $47 \cdot 0$ & & $45 \cdot 3$ & & 43.7 & & $43 \cdot 4$ & & $45 \cdot 3$ & & $46 \cdot 3$ \\
\hline \multirow[t]{10}{*}{ Women } & $\begin{array}{l}\text { Pasta with tomato } \\
\text { sauce or cheese }\end{array}$ & 6.5 & Butter & $7 \cdot 2$ & Butter & $5 \cdot 3$ & Cheese & 6.8 & Butter & 6.0 & Cheese & 7.5 \\
\hline & $\begin{array}{l}\text { Ice cream, ice milk } \\
\text { or frozen yogurt }\end{array}$ & $6 \cdot 2$ & $\begin{array}{l}\text { Ice cream, ice milk } \\
\text { or frozen yogurt }\end{array}$ & $5 \cdot 1$ & $\begin{array}{l}\text { Ice cream, ice milk } \\
\text { or frozen yogurt }\end{array}$ & 4.6 & Low-fat milk & 4.6 & $\begin{array}{l}\text { Pasta with tomato } \\
\text { sauce or cheese }\end{array}$ & $5 \cdot 6$ & $\begin{array}{l}\text { Pasta with tomato } \\
\text { sauce or cheese }\end{array}$ & 7.5 \\
\hline & $\begin{array}{l}\text { Chicken or turkey } \\
\text { dishes }\end{array}$ & $5 \cdot 8$ & $\begin{array}{l}\text { Burgers, meatballs } \\
\text { or patties }\end{array}$ & 4.6 & $\begin{array}{l}\text { Chicken or turkey } \\
\text { dishes }\end{array}$ & 4.3 & $\begin{array}{l}\text { Pasta with tomato } \\
\text { sauce or cheese }\end{array}$ & 4.6 & Cheese & $5 \cdot 1$ & Butter & 6.7 \\
\hline & Butter & 5.7 & $\begin{array}{l}\text { Pasta with tomato } \\
\text { sauce or cheese }\end{array}$ & 4.3 & $\begin{array}{l}\text { Pasta with tomato } \\
\text { sauce or cheese }\end{array}$ & 4.2 & Butter & 4.4 & $\begin{array}{l}\text { Ice cream, ice milk } \\
\text { or frozen yogurt }\end{array}$ & 4.7 & $\begin{array}{l}\text { Ice cream, ice milk } \\
\text { or frozen yogurt }\end{array}$ & 5.0 \\
\hline & Cheese & 4.9 & Beef and lamb & 4.0 & $\begin{array}{l}\text { Stir-fried meat and } \\
\text { vegetables }\end{array}$ & $4 \cdot 1$ & $\begin{array}{l}\text { Chicken or turkey } \\
\text { dishes }\end{array}$ & 4.4 & $\begin{array}{l}\text { Chicken or turkey } \\
\text { dishes }\end{array}$ & $4 \cdot 3$ & Low-fat milk & 3.7 \\
\hline & $\begin{array}{l}\text { Burgers, meatballs } \\
\text { or patties }\end{array}$ & 3.6 & Spam or bologna & 3.9 & $\begin{array}{l}\text { Burgers, meatballs } \\
\text { or patties }\end{array}$ & 3.7 & Pizza & 3.9 & $\begin{array}{l}\text { Burgers, meatballs } \\
\text { or patties }\end{array}$ & 3.7 & $\begin{array}{l}\text { Burgers, meatballs } \\
\text { or patties }\end{array}$ & 3.4 \\
\hline & Pork and ham & 3.5 & $\begin{array}{l}\text { Chicken or turkey } \\
\text { dishes }\end{array}$ & 3.8 & Spam or bologna & 3.5 & Pork and ham & 3.8 & Beef and lamb & 3.4 & $\begin{array}{l}\text { Chicken or turkey } \\
\text { dishes }\end{array}$ & 3.4 \\
\hline & Low-fat milk & 3.1 & Pork and ham & 3.7 & Beef and lamb & 3.5 & $\begin{array}{l}\text { Burgers, meatballs } \\
\text { or patties }\end{array}$ & 3.8 & Pork and ham & 3.4 & Chocolate candy & $3 \cdot 1$ \\
\hline & $\begin{array}{l}\text { Crackers, chips or } \\
\text { popcorn }\end{array}$ & $3 \cdot 1$ & Cheese & 3.5 & $\begin{array}{l}\text { Peanuts or other } \\
\text { nuts }\end{array}$ & 3.1 & Beef and lamb & 3.5 & Spam or bologna & 3.2 & Bread & 2.9 \\
\hline & Chocolate candy & 2.9 & Low-fat milk & 2.9 & Meat soups or stew & $3 \cdot 1$ & Taco salad & 3.5 & Low-fat milk & 2.9 & Beef and lamb & 2.7 \\
\hline Total (\%) & & $45 \cdot 3$ & & 43.0 & & 39.4 & & $43 \cdot 3$ & & $42 \cdot 3$ & & 45.9 \\
\hline
\end{tabular}

AfAm, African-American; NH, Native Hawaiian; JpAm, Japanese-American.

*Participants in the Multiethnic Cohort Study in Hawaii and Los Angeles. 
Table 5. Ten major sources of 'protein' and the percentage (\%) contribution of each item in each ethnic-sex group*

\begin{tabular}{|c|c|c|c|c|c|c|c|c|c|c|c|c|}
\hline & \multicolumn{2}{|l|}{ AfAm } & \multicolumn{2}{|l|}{$\mathrm{NH}$} & \multicolumn{2}{|l|}{ JpAm } & \multicolumn{2}{|c|}{ Latinos-Mexico } & \multicolumn{2}{|c|}{ Latinos-US } & \multicolumn{2}{|c|}{ Caucasian } \\
\hline & Food items & $\begin{array}{c}\% \text { Contri- } \\
\text { bution }\end{array}$ & Foods items & $\begin{array}{l}\% \text { Contri- } \\
\text { bution }\end{array}$ & Foods items & $\begin{array}{c}\% \text { Contri- } \\
\text { bution }\end{array}$ & Foods items & $\begin{array}{l}\% \text { Contri- } \\
\text { bution }\end{array}$ & Foods items & $\begin{array}{c}\% \text { Contri- } \\
\text { bution }\end{array}$ & Foods items & $\begin{array}{c}\% \text { Contri- } \\
\text { bution }\end{array}$ \\
\hline \multirow[t]{10}{*}{ Men } & $\begin{array}{l}\text { Chicken or turkey } \\
\text { dishes }\end{array}$ & $13 \cdot 3$ & $\begin{array}{l}\text { Chicken or turkey } \\
\text { dishes }\end{array}$ & 8.8 & Rice & 12.7 & $\begin{array}{l}\text { Chicken or turkey } \\
\text { dishes }\end{array}$ & 7.9 & $\begin{array}{l}\text { Chicken or turkey } \\
\text { dishes }\end{array}$ & $10 \cdot 1$ & $\begin{array}{l}\text { Chicken or turkey } \\
\text { dishes }\end{array}$ & 9.6 \\
\hline & Bread & $6 \cdot 1$ & Rice & 8.8 & $\begin{array}{l}\text { Chicken or turkey } \\
\text { dishes }\end{array}$ & 9.8 & Bread & 7.6 & Rice & 7.9 & Bread & $6 \cdot 1$ \\
\hline & $\begin{array}{l}\text { Burgers, meatballs } \\
\text { or patties }\end{array}$ & $5 \cdot 1$ & Fish & 7.5 & Fish & $7 \cdot 7$ & Taco salad & 6.9 & Bread & 5.6 & $\begin{array}{l}\text { Pasta with tomato } \\
\text { sauce or cheese }\end{array}$ & 6.0 \\
\hline & Fish & 4.8 & Bread & $5 \cdot 1$ & Bread & 4.7 & Beef and lamb & $5 \cdot 3$ & Fish & 5.5 & Fish & 5.0 \\
\hline & Rice & 4.5 & $\begin{array}{l}\text { Burgers, meatballs } \\
\text { or patties }\end{array}$ & 4.6 & $\begin{array}{l}\text { Stir-fried meat and } \\
\text { vegetables }\end{array}$ & 4.3 & Rice & 4.1 & $\begin{array}{l}\text { Burgers, meatballs } \\
\text { or patties }\end{array}$ & 4.6 & $\begin{array}{l}\text { Burgers, meatballs } \\
\text { or patties }\end{array}$ & 4.8 \\
\hline & $\begin{array}{l}\text { Pasta with tomato } \\
\text { sauce or cheese }\end{array}$ & 4.4 & Beef and lamb & 4.6 & Beef and lamb & $4 \cdot 0$ & Fish & $4 \cdot 0$ & Beef and lamb & $4 \cdot 3$ & Beef and lamb & 3.8 \\
\hline & Pork and ham & $4 \cdot 3$ & Pork and ham & 4.5 & $\begin{array}{l}\text { Burgers, meatballs } \\
\text { or patties }\end{array}$ & 3.8 & Cheese & 3.7 & Pork and ham & 4.0 & Cheese & 3.7 \\
\hline & Beef and lamb & $3 \cdot 2$ & $\begin{array}{l}\text { Stir-fried meat and } \\
\text { vegetables }\end{array}$ & 3.7 & Pork and ham & 3.5 & Meat soups or stew & 3.6 & $\begin{array}{l}\text { Pasta with tomato } \\
\text { sauce or cheese }\end{array}$ & 3.9 & Rice & 3.6 \\
\hline & Cereals & 2.9 & $\begin{array}{l}\text { Pasta with tomato } \\
\text { sauce or cheese }\end{array}$ & 3.0 & Meat soups or stew & 3.0 & $\begin{array}{l}\text { Burgers, meatballs } \\
\text { or patties }\end{array}$ & $3 \cdot 2$ & $\begin{array}{l}\text { Stir-fried meat and } \\
\text { vegetables }\end{array}$ & $3 \cdot 2$ & Pork and ham & 3.4 \\
\hline & $\begin{array}{l}\text { Stir-fried meat and } \\
\text { vegetables }\end{array}$ & $2 \cdot 3$ & Meat soups or stew & 3.0 & $\begin{array}{l}\text { Pasta with tomato } \\
\text { sauce or cheese }\end{array}$ & 3.0 & Meat burritos & 3.0 & Meat soups or stew & 3.0 & Cereals & 3.0 \\
\hline Total (\%) & & 50.9 & & $53 \cdot 6$ & & 56.5 & & $49 \cdot 3$ & & $52 \cdot 1$ & & 49.0 \\
\hline \multirow[t]{10}{*}{ Women } & $\begin{array}{l}\text { Chicken or turkey } \\
\text { dishes }\end{array}$ & 13.8 & $\begin{array}{l}\text { Chicken or turkey } \\
\text { dishes }\end{array}$ & 9.0 & Rice & $10 \cdot 4$ & $\begin{array}{l}\text { Chicken or turkey } \\
\text { dishes }\end{array}$ & 11.8 & $\begin{array}{l}\text { Chicken or turkey } \\
\text { dishes }\end{array}$ & $10 \cdot 2$ & $\begin{array}{l}\text { Chicken or turkey } \\
\text { dishes }\end{array}$ & $10 \cdot 2$ \\
\hline & Bread & 5.8 & Fish & 6.9 & $\begin{array}{l}\text { Chicken or turkey } \\
\text { dishes }\end{array}$ & 9.6 & Cheese & 4.6 & Bread & 6.4 & Bread & $7 \cdot 2$ \\
\hline & Fish & $5 \cdot 2$ & Rice & 6.4 & Fish & 6.9 & Bread & 4.6 & Rice & $6 \cdot 2$ & $\begin{array}{l}\text { Pasta with tomato } \\
\text { sauce or cheese }\end{array}$ & 6.3 \\
\hline & $\begin{array}{l}\text { Pasta with tomato } \\
\text { sauce or cheese }\end{array}$ & $5 \cdot 1$ & Bread & 5.7 & Bread & 5.8 & $\begin{array}{l}\text { Pasta with tomato } \\
\text { sauce or cheese }\end{array}$ & 3.8 & Fish & $5 \cdot 2$ & Fish & 4.8 \\
\hline & $\begin{array}{l}\text { Stir-fried meat and } \\
\text { vegetables }\end{array}$ & 3.4 & $\begin{array}{l}\text { Burgers, meatballs } \\
\text { or patties }\end{array}$ & $4 \cdot 3$ & $\begin{array}{l}\text { Stir-fried meat and } \\
\text { vegetables }\end{array}$ & $5 \cdot 0$ & Cereals & 3.7 & $\begin{array}{l}\text { Pasta with tomato } \\
\text { sauce or cheese }\end{array}$ & 4.5 & Cheese & 4.6 \\
\hline & $\begin{array}{l}\text { Burgers, meatballs } \\
\text { or patties }\end{array}$ & $3 \cdot 2$ & $\begin{array}{l}\text { Stir-fried meat and } \\
\text { vegetables }\end{array}$ & 3.8 & $\begin{array}{l}\text { Pasta with tomato } \\
\text { sauce or cheese }\end{array}$ & 3.4 & Pork and ham & 3.7 & $\begin{array}{l}\text { Stir-fried meat and } \\
\text { vegetables }\end{array}$ & 3.9 & Non-fat milk & 3.5 \\
\hline & Rice & 3.2 & Beef and lamb & 3.7 & Beef and lamb & 3.1 & Low-fat milk & 3.5 & $\begin{array}{l}\text { Burgers, meatballs } \\
\text { or patties }\end{array}$ & 3.5 & $\begin{array}{l}\text { Burgers, meatballs } \\
\text { or patties }\end{array}$ & 3.3 \\
\hline & Cereals & 3.1 & $\begin{array}{l}\text { Pasta with tomato } \\
\text { sauce or cheese }\end{array}$ & 3.7 & $\begin{array}{l}\text { Burgers, meatballs } \\
\text { or patties }\end{array}$ & $3 \cdot 1$ & $\begin{array}{l}\text { Burgers, meatballs } \\
\text { or patties }\end{array}$ & 3.4 & Beef and lamb & 3.4 & Cereals & $3 \cdot 2$ \\
\hline & Pork and ham & 3.1 & Pork and ham & 3.7 & $\begin{array}{l}\text { Broth with meat or } \\
\text { noodles }\end{array}$ & $3 \cdot 0$ & Beef and lamb & $3 \cdot 1$ & Pork and ham & $3 \cdot 3$ & Low-fat milk & $3 \cdot 0$ \\
\hline & Cheese & 2.6 & $\begin{array}{l}\text { Broth with meat or } \\
\text { noodles }\end{array}$ & 2.9 & Non-fat milk & 2.9 & Fish & 3.0 & Cheese & 3.0 & Rice & 3.0 \\
\hline Total (\%) & & 48.5 & & 50.1 & & $53 \cdot 2$ & & $45 \cdot 2$ & & 49.6 & & $49 \cdot 1$ \\
\hline
\end{tabular}


Table 6. Ten major sources of 'dietary fibre' and the percentage (\%) contribution of each item in each ethnic-sex group*

\begin{tabular}{|c|c|c|c|c|c|c|c|c|c|c|c|c|}
\hline & \multicolumn{2}{|l|}{ AfAm } & \multicolumn{2}{|l|}{$\mathrm{NH}$} & \multicolumn{2}{|l|}{ JpAm } & \multicolumn{2}{|c|}{ Latinos-Mexico } & \multicolumn{2}{|c|}{ Latinos-US } & \multicolumn{2}{|c|}{ Caucasian } \\
\hline & Food items & $\begin{array}{c}\% \text { Contri- } \\
\text { bution }\end{array}$ & Foods items & $\begin{array}{c}\% \text { Contri- } \\
\text { bution }\end{array}$ & Foods items & $\begin{array}{c}\% \text { Contri- } \\
\text { bution }\end{array}$ & Foods items & $\begin{array}{c}\% \text { Contri- } \\
\text { bution }\end{array}$ & Foods items & $\begin{array}{c}\% \text { Contri- } \\
\text { bution }\end{array}$ & Foods items & $\begin{array}{c}\% \text { Contri- } \\
\text { bution }\end{array}$ \\
\hline \multirow[t]{10}{*}{ Men } & Bread & 10.7 & Bread & $10 \cdot 0$ & Cereals & 9.3 & Bread & 13.5 & Bread & $10 \cdot 2$ & Cereals & 11.4 \\
\hline & Cereals & 10.5 & Cereals & 8.2 & Bread & 9.0 & Beans & 6.3 & Cereals & 8.9 & Bread & 10.6 \\
\hline & $\begin{array}{l}\text { Orange, grapefruit } \\
\text { or pomelo }\end{array}$ & $6 \cdot 9$ & $\begin{array}{l}\text { Orange, grapefruit } \\
\text { or pomelo }\end{array}$ & $6 \cdot 1$ & Rice & 8.4 & $\begin{array}{l}\text { Orange, grapefruit } \\
\text { or pomelo }\end{array}$ & $5 \cdot 6$ & $\begin{array}{l}\text { Orange, grapefruit } \\
\text { or pomelo }\end{array}$ & $5 \cdot 8$ & $\begin{array}{l}\text { Crackers, chips or } \\
\text { popcorn }\end{array}$ & $5 \cdot 0$ \\
\hline & $\begin{array}{l}\text { Crackers, chips or } \\
\text { popcorn }\end{array}$ & 4.8 & Rice & $5 \cdot 6$ & $\begin{array}{l}\text { Orange, grapefruit } \\
\text { or pomelo }\end{array}$ & 6.4 & Cereals & 5.6 & Rice & $5 \cdot 3$ & $\begin{array}{l}\text { Orange, grapefruit } \\
\text { or pomelo }\end{array}$ & 5.0 \\
\hline & Beans & 4.8 & Bananas & 4.0 & Bananas & 4.7 & Bananas & $5 \cdot 2$ & Bananas & 4.3 & Bananas & 4.5 \\
\hline & Bananas & $4 \cdot 3$ & Tropical fruits & $3 \cdot 1$ & Tropical fruits & 4.0 & $\begin{array}{l}\text { Crackers, chips or } \\
\text { popcorn }\end{array}$ & $4 \cdot 1$ & Beans & $4 \cdot 3$ & Beans & 3.7 \\
\hline & $\begin{array}{l}\text { Apples or } \\
\text { applesauce }\end{array}$ & 3.4 & Taro & 2.9 & $\begin{array}{l}\text { Apples or apple- } \\
\text { sauce }\end{array}$ & 3.0 & $\begin{array}{l}\text { Apples or } \\
\text { applesauce }\end{array}$ & 3.6 & $\begin{array}{l}\text { Crackers, chips or } \\
\text { popcorn }\end{array}$ & $4 \cdot 1$ & $\begin{array}{l}\text { Pasta with tomato } \\
\text { sauce or cheese }\end{array}$ & 3.5 \\
\hline & Rice & 3.0 & $\begin{array}{l}\text { Crackers, chips or } \\
\text { popcorn }\end{array}$ & 2.9 & $\begin{array}{l}\text { Peanuts or other } \\
\text { nuts }\end{array}$ & $2 \cdot 9$ & Vegetable soups & $3 \cdot 2$ & $\begin{array}{l}\text { Apples or apple- } \\
\text { sauce }\end{array}$ & 2.9 & $\begin{array}{l}\text { Apples or } \\
\text { applesauce }\end{array}$ & 3.4 \\
\hline & Other fruits & $2 \cdot 7$ & $\begin{array}{l}\text { Peanuts or other } \\
\text { nuts }\end{array}$ & 2.5 & $\begin{array}{l}\text { Stir-fried meat and } \\
\text { vegetables }\end{array}$ & $2 \cdot 7$ & Taco salad & $3 \cdot 1$ & Tropical fruits & $2 \cdot 6$ & Tropical fruits & $2 \cdot 8$ \\
\hline & $\begin{array}{l}\text { Broccoli or } \\
\text { cauliflower }\end{array}$ & 2.5 & Beans & 2.5 & Dark greens & 2.5 & $\begin{array}{l}\text { Green beans or } \\
\text { peas }\end{array}$ & $2 \cdot 8$ & Vegetable soups & 2.5 & $\begin{array}{l}\text { Peanuts or other } \\
\text { nuts }\end{array}$ & $2 \cdot 8$ \\
\hline Total (\%) & & $53 \cdot 6$ & & $47 \cdot 8$ & & $52 \cdot 9$ & & 53.0 & & $50 \cdot 9$ & & 52.7 \\
\hline \multirow{10}{*}{ Women } & Cereals & $10 \cdot 3$ & Bread & 9.7 & Bread & 9.3 & Cereals & $12 \cdot 2$ & Bread & 10.5 & Bread & $11 \cdot 1$ \\
\hline & Bread & 8.9 & Cereals & 8.4 & Cereals & 8.9 & Bread & 8.0 & Cereals & $9 \cdot 0$ & Cereals & 10.4 \\
\hline & $\begin{array}{l}\text { Crackers, chips or } \\
\text { popcorn }\end{array}$ & 6.6 & $\begin{array}{l}\text { Orange, grapefruit } \\
\text { or pomelo }\end{array}$ & 6.5 & $\begin{array}{l}\text { Orange, grapefruit } \\
\text { or pomelo }\end{array}$ & 7.7 & $\begin{array}{l}\text { Orange, grapefruit } \\
\text { or pomelo }\end{array}$ & 7.4 & $\begin{array}{l}\text { Orange, grapefruit } \\
\text { or pomelo }\end{array}$ & 5.7 & $\begin{array}{l}\text { Orange, grapefruit } \\
\text { or pomelo }\end{array}$ & $5 \cdot 2$ \\
\hline & $\begin{array}{l}\text { Orange, grapefruit } \\
\text { or pomelo }\end{array}$ & 5.9 & Bananas & 4.5 & Rice & $6 \cdot 2$ & Beans & 6.9 & Bananas & $5 \cdot 0$ & Bananas & 4.9 \\
\hline & $\begin{array}{l}\text { Apples or } \\
\text { applesauce }\end{array}$ & 4.4 & Tropical fruits & 3.9 & Bananas & $5 \cdot 3$ & Bananas & $6 \cdot 3$ & $\begin{array}{l}\text { Crackers, chips or } \\
\text { popcorn }\end{array}$ & 4.4 & $\begin{array}{l}\text { Crackers, chips, } \\
\text { popcorn }\end{array}$ & 4.7 \\
\hline & Beans & 4.4 & $\begin{array}{l}\text { Crackers, chips or } \\
\text { popcorn }\end{array}$ & 3.6 & Tropical fruits & $5 \cdot 1$ & Tropical fruits & 4.7 & Beans & 3.9 & $\begin{array}{l}\text { Apples or } \\
\text { applesauce }\end{array}$ & 3.7 \\
\hline & Bananas & $4 \cdot 2$ & Rice & 3.6 & $\begin{array}{l}\text { Apples or } \\
\text { applesauce }\end{array}$ & 3.5 & $\begin{array}{l}\text { Broccoli or } \\
\text { cauliflower }\end{array}$ & 2.9 & Rice & 3.6 & Tropical fruits & 3.6 \\
\hline & $\begin{array}{l}\text { Broccoli or } \\
\text { cauliflower }\end{array}$ & 3.7 & Taro & 3.1 & Other fruits & 3.0 & Other fruits & 2.8 & Tropical fruits & 3.5 & Beans & 3.4 \\
\hline & Other fruits & $3 \cdot 2$ & $\begin{array}{l}\text { Apples or } \\
\text { applesauce }\end{array}$ & 3.0 & Carrots & 3.0 & Vegetable soups & $2 \cdot 7$ & Other fruits & 3.1 & $\begin{array}{l}\text { Pasta with tomato } \\
\text { sauce or cheese }\end{array}$ & $3 \cdot 3$ \\
\hline & Tropical fruits & $2 \cdot 8$ & Other fruits & 2.9 & Dark greens & 2.9 & $\begin{array}{l}\text { Apples or } \\
\text { applesauce }\end{array}$ & $2 \cdot 6$ & $\begin{array}{l}\text { Apples or } \\
\text { applesauce }\end{array}$ & $3 \cdot 0$ & Carrots & 3.3 \\
\hline Total (\%) & & 54.4 & & $49 \cdot 2$ & & 54.9 & & 56.5 & & $51 \cdot 7$ & & $53 \cdot 6$ \\
\hline
\end{tabular}

AfAm, African-American; NH, Native Hawaiian; JpAm, Japanese-American.

*Participants in the Multiethnic Cohort Study in Hawaii and Los Angeles. 
Table 7. Ten major sources of 'added sugar' and the percentage (\%) contribution of each item in each ethnic-sex group*

\begin{tabular}{|c|c|c|c|c|c|c|c|c|c|c|c|c|}
\hline & \multicolumn{2}{|l|}{ AfAm } & \multicolumn{2}{|l|}{$\mathrm{NH}$} & \multicolumn{2}{|l|}{ JpAm } & \multicolumn{2}{|c|}{ Latinos-Mexico } & \multicolumn{2}{|l|}{ Latinos-US } & \multicolumn{2}{|l|}{ Caucasian } \\
\hline & Food items & $\begin{array}{l}\% \text { Contri- } \\
\text { bution }\end{array}$ & Foods items & $\begin{array}{l}\% \text { Contri- } \\
\text { bution }\end{array}$ & Foods items & $\begin{array}{l}\% \text { Contri- } \\
\text { bution }\end{array}$ & Foods items & $\begin{array}{l}\% \text { Contri- } \\
\text { bution }\end{array}$ & Foods items & $\begin{array}{l}\% \text { Contri- } \\
\text { bution }\end{array}$ & Foods items & $\begin{array}{l}\% \text { Contri- } \\
\text { bution }\end{array}$ \\
\hline \multirow[t]{10}{*}{ Men } & Regular sodas & $31 \cdot 8$ & Regular sodas & 34.5 & Regular sodas & 28.4 & Regular sodas & $35 \cdot 2$ & Regular sodas & $28 \cdot 7$ & Regular sodas & $25 \cdot 7$ \\
\hline & Ice cream & 6.4 & $\begin{array}{l}\text { Other fruit juices or } \\
\text { drinks }\end{array}$ & 7.9 & $\begin{array}{l}\text { Other fruit juices or } \\
\text { drinks }\end{array}$ & 6.9 & $\begin{array}{l}\text { Other fruit juices or } \\
\text { drinks }\end{array}$ & 3.9 & Ice cream & $6 \cdot 1$ & Chocolate candy & 5.8 \\
\hline & Cakes & 4.8 & Ice cream & 5.5 & Chocolate candy & 4.9 & $\begin{array}{l}\text { Pancakes or French } \\
\text { toast }\end{array}$ & 3.9 & Cookies or fruit bars & 4.5 & $\begin{array}{l}\text { Other fruit juices or } \\
\text { drinks }\end{array}$ & $5 \cdot 6$ \\
\hline & $\begin{array}{l}\text { Other fruit juices or } \\
\text { drinks }\end{array}$ & 4.7 & Chocolate candy & 4.4 & Ice cream & 4.9 & Milkshakes or malts & 3.9 & $\begin{array}{l}\text { Other fruit juices or } \\
\text { drinks }\end{array}$ & 4.4 & Ice cream & 5.5 \\
\hline & $\begin{array}{l}\text { Pancakes or French } \\
\text { toast }\end{array}$ & 4.0 & $\begin{array}{l}\text { Pancakes or French } \\
\text { toast }\end{array}$ & 4.2 & $\begin{array}{l}\text { Pancakes or French } \\
\text { toast }\end{array}$ & 4.7 & Ice cream & 3.9 & $\begin{array}{l}\text { Pancakes or French } \\
\text { toast }\end{array}$ & $4 \cdot 3$ & Cookies or fruit bars & $5 \cdot 0$ \\
\hline & Cookies or fruit bars & 4.0 & $\begin{array}{l}\text { Chocolate milk or } \\
\text { cocoa }\end{array}$ & 3.3 & Cookies or fruit bars & 3.3 & Cappuccino & 3.6 & $\begin{array}{l}\text { Sweet rolls or coffee } \\
\text { cakes }\end{array}$ & 4.1 & $\begin{array}{l}\text { Pancakes or French } \\
\text { toast }\end{array}$ & 4.2 \\
\hline & Chocolate candy & 3.6 & Cookies or fruit bars & 2.7 & Sugar & 3.0 & Cookies or fruit bars & 3.4 & Chocolate candy & $4 \cdot 1$ & $\begin{array}{l}\text { Ice milk or frozen } \\
\text { yogurt }\end{array}$ & 3.9 \\
\hline & $\begin{array}{l}\text { Ice milk or frozen } \\
\text { yogurt }\end{array}$ & 2.9 & Cakes & $2 \cdot 3$ & Jam or jelly & 2.9 & Sugar & 3.3 & Sugar & 2.9 & $\begin{array}{l}\text { Bran or high-fibre } \\
\text { cereals }\end{array}$ & 3.0 \\
\hline & $\begin{array}{l}\text { Sweet rolls or coffee } \\
\text { cakes }\end{array}$ & 2.9 & $\begin{array}{l}\text { Sweet rolls or coffee } \\
\text { cakes }\end{array}$ & $2 \cdot 2$ & $\begin{array}{l}\text { Ice milk or frozen } \\
\text { yogurt }\end{array}$ & $2 \cdot 7$ & Cakes & $3 \cdot 2$ & Cakes & 2.9 & Cakes & $2 \cdot 8$ \\
\hline & Sugar & $2 \cdot 3$ & Sugar & $2 \cdot 1$ & Cakes & $2 \cdot 6$ & $\begin{array}{l}\text { Chocolate milk or } \\
\text { cocoa }\end{array}$ & 3.2 & $\begin{array}{l}\text { Chocolate milk or } \\
\text { cocoa }\end{array}$ & $2 \cdot 8$ & $\begin{array}{l}\text { Chocolate milk or } \\
\text { cocoa }\end{array}$ & $2 \cdot 6$ \\
\hline Total (\%) & & $67 \cdot 4$ & & $69 \cdot 1$ & & $64 \cdot 3$ & & 67.5 & & $64 \cdot 8$ & & $64 \cdot 1$ \\
\hline \multirow[t]{10}{*}{ Women } & Regular sodas & $29 \cdot 3$ & Regular sodas & 30.2 & Regular sodas & 17.5 & Regular sodas & $24 \cdot 6$ & Regular sodas & $25 \cdot 1$ & Regular sodas & $17 \cdot 2$ \\
\hline & $\begin{array}{l}\text { Other fruit juices or } \\
\text { drinks }\end{array}$ & 6.4 & $\begin{array}{l}\text { Other fruit juices or } \\
\text { drinks }\end{array}$ & $9 \cdot 1$ & $\begin{array}{l}\text { Other fruit juices or } \\
\text { drinks }\end{array}$ & $9 \cdot 0$ & $\begin{array}{l}\text { Other fruit juices or } \\
\text { drinks }\end{array}$ & $6 \cdot 3$ & $\begin{array}{l}\text { Other fruit juices or } \\
\text { drinks }\end{array}$ & $6 \cdot 1$ & Chocolate candy & 7.5 \\
\hline & Ice cream & $5 \cdot 1$ & Chocolate candy & $5 \cdot 3$ & Chocolate candy & 6.9 & Cappuccino & 4.7 & Ice cream & 4.8 & $\begin{array}{l}\text { Other fruit juices or } \\
\text { drinks }\end{array}$ & 6.5 \\
\hline & Cakes & 4.5 & Ice cream & $4 \cdot 2$ & $\begin{array}{l}\text { Pancakes or French } \\
\text { toast }\end{array}$ & 4.5 & Milkshakes or malts & 4.1 & Chocolate candy & 4.5 & Cookies or fruit bars & $5 \cdot 2$ \\
\hline & Chocolate candy & 4.5 & $\begin{array}{l}\text { Pancakes or French } \\
\text { toast }\end{array}$ & 4.0 & Ice cream & 3.9 & $\begin{array}{l}\text { Pancakes or French } \\
\text { toast }\end{array}$ & 3.9 & Cookies or fruit bars & 4.2 & $\begin{array}{l}\text { Ice milk or frozen } \\
\text { yogurt }\end{array}$ & 5.0 \\
\hline & $\begin{array}{l}\text { Ice milk or frozen } \\
\text { yogurt }\end{array}$ & 3.8 & $\begin{array}{l}\text { Chocolate milk or } \\
\text { cocoa }\end{array}$ & 3.4 & Cookies or fruit bars & 3.8 & Sugar & 3.8 & $\begin{array}{l}\text { Pancakes or French } \\
\text { toast }\end{array}$ & 3.9 & Ice cream & 4.4 \\
\hline & Cookies or fruit bars & 3.3 & $\begin{array}{l}\text { Ice milk or frozen } \\
\text { yogurt }\end{array}$ & $2 \cdot 8$ & Jam or jelly & 3.7 & Ice cream & 3.4 & $\begin{array}{l}\text { Sweet rolls or coffee } \\
\text { cakes }\end{array}$ & 3.7 & Yogurt & 4.1 \\
\hline & $\begin{array}{l}\text { Pancakes or French } \\
\text { toast }\end{array}$ & 3.0 & Cookies or fruit bars & $2 \cdot 6$ & $\begin{array}{l}\text { Ice milk or frozen } \\
\text { yogurt }\end{array}$ & 3.3 & Cookies or fruit bars & 3.4 & $\begin{array}{l}\text { Ice milk or frozen } \\
\text { yogurt }\end{array}$ & 3.3 & $\begin{array}{l}\text { Pancakes or French } \\
\text { toast }\end{array}$ & 3.8 \\
\hline & $\begin{array}{l}\text { Bran or high-fibre } \\
\text { cereals }\end{array}$ & $2 \cdot 4$ & Cakes & $2 \cdot 3$ & Cakes & $3 \cdot 1$ & $\begin{array}{l}\text { Chocolate milk or } \\
\text { cocoa }\end{array}$ & $3 \cdot 1$ & $\begin{array}{l}\text { Chocolate milk or } \\
\text { cocoa }\end{array}$ & 3.0 & $\begin{array}{l}\text { Bran or high-fibre } \\
\text { cereals }\end{array}$ & 3.2 \\
\hline & $\begin{array}{l}\text { Chocolate milk or } \\
\text { cocoa }\end{array}$ & $2 \cdot 3$ & $\begin{array}{l}\text { Sweet rolls or coffee } \\
\text { cakes }\end{array}$ & $2 \cdot 2$ & $\begin{array}{l}\text { Bran or high-fibre } \\
\text { cereals }\end{array}$ & $2 \cdot 6$ & Cakes & $3 \cdot 1$ & Cakes & $2 \cdot 8$ & $\begin{array}{l}\text { Chocolate milk or } \\
\text { cocoa }\end{array}$ & 3.0 \\
\hline Total (\%) & & 64.6 & & $66 \cdot 1$ & & 58.3 & & 60.4 & & $61 \cdot 4$ & & 59.9 \\
\hline
\end{tabular}


population reaching 102.5 million in 2007 , or $34 \%$ of the total $^{(21)}$. It has been shown that ethnic/racial groups are adopting US dietary practices, which are typically high in fat and low in fruits and vegetables ${ }^{(22)}$. This trend is particularly alarming when observed in combination with other lifestyle changes, such as decreased physical activity, which may also increase the risk for chronic disease ${ }^{(4)}$. In the present study, we found that the Latino-US group identified different dietary sources of energy and other nutrients compared with the foods consumed by the Latino-Mexico group. For example, while peanuts/other nuts were a top contributor to total fat intake for Latino-US, peanuts/other nuts did not appear among the major sources for Latino-Mexico. Instead, taco salad was a top-ten contributor to total fat among LatinoMexico compared with Latino-US, for whom taco salad was not an important source. Ethnic differences in dietary sources, as described in the present study, demonstrate a need to consider cultural identities and unique customs when formulating and conveying public health messages and developing and implementing nutrition education and intervention programmes aimed at improving food choices among diverse populations.

While numerous ethnic differences in major dietary sources of energy, total fat, saturated fat, protein, dietary fibre and added sugar have been noted between ethnic/racial groups, an appreciable similarity exists in dietary consumption patterns, consistent among all groups represented in the MEC. Some similarities would be expected, given that the MEC participants were recruited primarily from residents living in two specific geographic areas of the USA. Of note, regular sodas were the primary source of added sugar across all ethnic-sex groups. Combined, regular sodas and other fruit juices/drinks contribute up to almost $50 \%$ to total added sugar consumption. These findings present a tremendous opportunity for public health advocates to help reduce the intake of added sugar, specifically the consumption of sugarsweetened beverages, which has been linked with an increased risk for a number of diet-related chronic diseases ${ }^{\text {(23) }}$.

The strengths of the present study include the large sample size and the population-specific dietary assessment instrument used to collect data. The MEC QFFQ was specifically developed and validated to describe dietary consumption patterns for the five ethnic/racial groups represented in the present study population. The non-Caucasian sample sizes generated for the MEC are substantially larger than those that are available from other national surveys. The CSFII 1994-6 collected dietary intake data from 16103 adults $^{(18)}$, which included AfAm and Latinos, but the samples were comparatively small. Furthermore, no national survey has sampled populations in Hawaii, a state that comprises a relatively large number of JpAm and NH. In addition, with the exception of a slightly higher education among cohort participants, baseline characteristics were comparable with census data, supporting the generalisability of these results to the larger US population $^{(14)}$.

Some limitations also warrant mention. Unfortunately, there were a relatively large number of exclusions due to missing data, and the proportion of excluded participants did vary somewhat for the different ethnic-sex groups, ranging from $15 \%$ in Caucasian and JpAm women, to only $2.5 \%$ for $\mathrm{NH}$ of both sexes. Although these differences do raise concern regarding introduction of selection bias, with the considerable sample sizes that were still maintained in these analyses, considerable dietary variation would have to have occurred in order to have an impact on these results. Recall bias is also a possible limitation; however, the QFFQ utilised in the MEC characterises total consumption relatively well as demonstrated in calibration and validation assessments ${ }^{(14,15)}$. Further, previous studies have demonstrated that FFQ are suitable tools for quantitative assessment of food and nutrient intake $^{(24)}$, although some have suggested that the validity may be higher among women ${ }^{(25)}$, and could vary by food group $^{(26)}$. Another limitation is the collection of data over 15 years ago, thus more recent data would be useful to determine whether changes in the dietary patterns of specific ethnic groups over time may have had an impact on the generalisability of these results to the current population. Nevertheless, no other study on the dietary sources exists for a large sample of the five main ethnic/racial groups in the USA.

\section{Conclusions}

The present study is the first to provide data on the major dietary sources of energy, total fat, saturated fat, protein, dietary fibre and added sugar across the main ethnic/racial minority groups in the USA. The present findings may be used to direct public health strategies and develop nutritional guidelines targeted for specific ethnic/racial populations. Continuing efforts to promote a healthful diet and improve food choices must bear special consideration of unique dietary needs distinct to each of these diverse population groups. The present dietary data are particularly valuable for identifying target foods for nutritional intervention programmes aimed at improving dietary adequacy and reducing the risk for chronic disease among the ethnic/racial populations represented in the MEC. Furthermore, these data will facilitate the ongoing investigation of diet-disease associations and observed health disparities among ethnic minority groups.

\section{Acknowledgements}

This study could not have been undertaken without the financial support of the following organisations to whom we are very grateful: the National Cancer Institute (grant no. R37 CA54821), the USDA (USDA-NRI New Investigator Award, grant no. 2002-00793) and the American Heart Association of Hawaii (Beginning Grant-in-Aid, grant no. 0265287Z). We also thank Thomas Brown for assistance with the data analysis, as well as Ms Eva Erber, Dr Tony Sheehy, Ms Alison Barr, Dr Mohammadreza Pakseresht and Dr Sara Schaefer for reviewing and editing the manuscript. S. S. and L. N. K. conceptualised the study. L. R. W. and L. S. were responsible for the data management and statistical analyses. S. S. drafted the original manuscript. All authors provided critical review and final approval of the manuscript. None of the authors has any conflicts of interest to report. 


\section{References}

1. Murphy SL, Xu J \& Kochanek KD (2012) NVSR, vol. 60. http://www.cdc.gov/nchs/data/nvsr/nvsr60/nvsr60_04.pdf (accessed 16 April 2012).

2. Centers for Disease Control and Prevention (2002) Health, United States, 2002. Rockville, MD: Department of Health and Human Services.

3. Mokdad AH, Marks JS, Stroup DF, et al. (2004) Actual causes of death in the United States, 2000. JAMA 291, $1238-1245$.

4. Centers for Disease Control and Prevention (2010) Chronic diseases and health promotion. Centers for Disease Control and Prevention Web site. http://www.cdc. gov/chronicdisease/overview/index.htm (accessed 30 April 2012)

5. Demark-Wahnefried W, Rock CL, Patrick K, et al. (2008) Lifestyle interventions to reduce cancer risk and improve outcomes. Am Fam Physician 77, 1573-1578.

6. Scarborough $\mathrm{P}$, Bhatnagar $\mathrm{P}$, Wickramasinghe $\mathrm{KK}$, et al. (2011) The economic burden of ill health due to diet, physical inactivity, smoking, alcohol and obesity in the UK: an update to 2006-07 NHS costs. J Public Health (Oxf) 33, 527-535.

7. Galimanis A, Mono ML, Arnold M, et al. (2009) Lifestyle and stroke risk: a review. Curr Opin Neurol 22, 60-68.

8. Eyre H, Kahn R \& Robertson RM (2004) Preventing cancer, cardiovascular disease, and diabetes: a common agenda for the American Cancer Society, the American Diabetes Association, and the American Heart Association. CA Cancer J Clin 54, 190-207.

9. US Department of Health and Human Services \& US Department of Agriculture (2010) Dietary Guidelines for Americans, 2010, 7th ed. Washington, DC: US Government Printing Office.

10. American Heart Association Nutrition Committee, Lichtenstein AH, Appel LJ, et al. (2006) Diet and lifestyle recommendations revision 2006: a scientific statement from the American Heart Association Nutrition Committee. Circulation 114, 82-96.

11. Kushi LH, Doyle C, McCullough M, et al. (2012) American cancer society guidelines on nutrition and physical activity for cancer prevention. CA Cancer J Clin 62, 30-67.

12. Bantle JP, Wylie-Rosett J, Albright AL, et al. (2008) Nutrition recommendations and interventions for diabetes: a position statement of the American Diabetes Association. Diabetes Care 31, Suppl. 1, S61-S78.
13. Flegal KM, Carroll MD, Ogden CL, et al. (2010) Prevalence and trends in obesity among US adults, 1999-2008. JAMA 303, 235-241.

14. Kolonel LN, Henderson BE, Hankin JH, et al. (2000) A multiethnic cohort in Hawaii and Los Angeles: baseline characteristics. Am J Epidemiol 151, 346-357.

15. Stram DO, Hankin JH, Wilkens LR, et al. (2000) Calibration of the dietary questionnaire for a multiethnic cohort in Hawaii and Los Angeles. Am J Epidemiol 151, 358-370.

16. Sharma S, Murphy SP, Wilkens LR, et al. (2003) Extending a multiethnic food composition table to include standardized food group servings. J Food Comp Anal 16, 485-495.

17. Cotton PA, Subar AF, Friday JE, et al. (2004) Dietary sources of nutrients among US adults, 1994 to 1996. J Am Diet Assoc 104, 921-930.

18. US Department of Agriculture (2004) 1994-96 Continuing Survey of Food Intakes by Individuals [CD-ROM]. Riverdale, MD: Agricultural Research Service.

19. Census Bureau (US) (2009) United States population projections: 2000 to 2050. http://www.census.gov/population/ www/projections/analytical-document09.pdf (accessed 30 April 2012).

20. Kandel WA (2011) The US foreign-born population: trends and selected characteristics, CRS Report for Congress, Congressional Research Service.

21. Bernstein R (2008) US Hispanic population surpasses 45 million US Census Bureau: Public Information Office. http://www.census.gov/newsroom/releases/archives/popul ation/cb08-67.html (accessed 30 April 2012).

22. Satia-Abouta J, Patterson RE, Neuhouser ML, et al. (2002) Dietary acculturation: applications to nutrition research and dietetics. J Am Diet Assoc 102, 1105-1118.

23. Hu FB \& Malik VS (2010) Sugar-sweetened beverages and risk of obesity and type 2 diabetes: epidemiological evidence. Physiol Behav 101, 47-54.

24. Ke L, Toshiro T, Fengyan S, et al. (2005) Relative validity of a semi-quantitative food frequency questionnaire versus 3 day weighed diet records in middle-aged inhabitants in Chaoshan area, China. Asian Pacific J Cancer Prev 6, 367-381.

25. Carithers TC, Talegawkar SA, Rowser ML, et al. (2009) Validity and calibration of food frequency questionnaires used with African-American adults in the Jackson Heart Study. J Am Diet Assoc 109, 1184-1193.

26. Marks GC, Hughes MC \& van der Pols JC (2006) Relative validity of food intake estimates using a food frequency questionnaire is associated with sex, age, and other personal characteristic. J Nutr 136, 459-465. 